\title{
Konsep Revolusi Mental Presiden Joko Widodo dalam Perspektif Pendidikan Karakter Syed Muhammad Naquib Al-Attas
}

\author{
${ }^{1}$ Sulthon Abdul Aziz dan ${ }^{2}$ Mohammad Syifa Amin Widigdo \\ ${ }^{1}$ Magister Studi Islam Program Pascasarjana Universitas Muhammadiyah Yogyakarta (UMY) \\ Jl. Brawijaya, Geblagan, Tamantirto, Kec. Kasihan, Bantul, Daerah Istimewa Yogyakarta 55183 \\ sulthon.isid@gmail.com \\ ${ }^{1}$ Fakultas Agama Islam Universitas Muhammadiyah Yogyakarta (UMY) \\ Jl. Brawijaya, Geblagan, Tamantirto, Kec. Kasihan, Bantul, Daerah Istimewa Yogyakarta 55183 \\ syifamin@gmail.com
}

\begin{abstract}
Abstrak
Penelitian ini ditujukan untuk mengetahui konsep revolusi mental Presiden Joko Widodo dalam perspektif pendidikan karakter Syed Muhammad Naquib Al-Attas. Metode penelitian yang digunakan adalah studi dokumen (document study) yang menitikberatkan pada kegiatan menganalisis bahan literatur atau dokumen, dengan pendekatan kualitatif dan tehnik analisis konten (content analysis). Sebagai hasilnya, peneliti menemukan beberapa perbedaan mendasar yang terjadi di antara konsep revolusi mental Jokowi dan konsep pendidikan karakter Al-Attas, dengan mengacu kepada empat pilar pendidikan UNESCO yaitu learn to know, learn to do, learn to live together, dan learn to be, yang dalam penelitian ini disebut secara berurutan dengan kognitif, psikomotorik, afektif, dan teleologis. Dari keempat aspek tersebut, ada dua aspek yang di dalamnya terjadi perbedaan, yaitu aspek kognitif dan teleologis. Pada aspek kognitif, revolusi mental Jokowi tidak memberikan penekanan yang besar terhadap ranah ini. Sementara AlAttas memberikan penekanan yang besar terhadap aspek afektif. Adapun pada aspek teleologis, konsep revolusi mental Jokowi bertujuan untuk mencetak warga negara yang baik, sementara Al-Attas bertujuan untuk mencetak manusia yang adil (insan kamil). Hasil analisis dari kedua konsep di atas adalah bahwa konsep revolusi mental Presiden Joko Widodo jika ditinjau dari perspektif pendidikan karakter Syed Muhammad Naquib Al-Attas sebenarnya telah menduduki konsep ta'dib, tapi pada level untuk menjadi khalifah. Serta ada perbedaan yang terjadi pada aspek kognitif, di mana konsep revolusi mental Jokowi hanya memberikan penekanan yang kecil pada sisi kognitif.
\end{abstract}

Kata Kunci: revolusi mental, pendidikan karakter, konsep ta’dib.

\begin{abstract}
This research aims to find out the mental revolution concept of president Joko Widodo viewed from the perspective of character education concept by Syed Muhammad Naquib Al-Attas. This research carried out a document study that focuses on analyzing the literature or documents using qualitative approach and content analysis technique. The findings show that there are significant differences between the mental revolution of Jokowi and character education concept of Syed Muhmmad Naquib Al-Attas referring to 4 pillars of UNESCO namely learn to know, learn to do, learn to live together, and learn to be which are called orderly as cognitive, psychomotor, affective and teleology in this research. Of those 4 aspects, the aspects of teleology and cognitive
\end{abstract}


have major differences. In the cognitive aspect, the mental revolution of Jokowi doesn't give a large focuses on it. Meanwhile, Syed Muhammad Naquib Al-Attas gives the mainly focuses for this aspect. In the aspect of teleology, the mental revolution by Jokowi aims to create good citizens, while it is to create just people (insan kamil) for Syed Muhammad Naquib Al-Attas. From those two aspects, it is concluded that the mental revolution concept of Jokowi when viewed by the perspective of character education of Syed Muhammad Naquib Al-Attas has been in ta'dib concept in order to be a khalifah. And there are still differences in the aspect of cognitive, that the mental revolution of Jokowi only gives a little focuses on the cognitive aspect

Keywords: the mental revolution, character education, concept of ta'dib.

\section{PENDAHULUAN}

Keanekaragaman ras, suku, agama, dan bahasa di Negara Kesatuan Republik Indonesia menjadikannya sebuah bangsa yang majemuk. Heterogenitas inilah yang oleh sebagian kalangan dianggap sebagai berkah dari Tuhan Yang Maha Esa karena dapat meningkatkan kualitas hidup bangsa. Namun di sisi lain, bangsa Indonesia kini tengah mengalami kemunduran, terutama dalam bidang pembangunan manusia. Menurut survei United Nations Development Programme (UNDP), Indonesia berada pada peringkat 108 dari 187 dalam hal pengembangan manusia. Juga menurut survei Programme for International Student Assesment (PISA) di mana Indonesia berada pada posisi 64 dari 65 negara dalam hal kemampuan literasi dan numerasi pada peserta didik. Kualitas pendidik di Indonesia juga menjadi satu keprihatinan, rata-rata kompetensi guru adalah 44,5 sedang standarnya adalah 75. Ditambah dengan tindak kriminal yang melibatkan pendidik dan peserta didik berupa kekerasan fisik atau seksual yang tercatat oleh Komisi Perlindungan Anak Indonesia (KPAI) sebanyak 228 kasus pada tahun 2018 dan tawuran antarpelajar sebanyak 144 kasus.

Melihat kondisi ini, Jokowi mencanangkan program revolusi mental yang selanjutnya dituangkan dalam berbagai naskah resmi negara, di antaranya: Inpres No. 12 Tahun 2016, Perpres No. 87 Tahun 2017, Permen PMK No. 3 Tahun 2017, Permen PMK No. 4 Tahun 2017, dan Permendikbud No. 20 Tahun 2018. Namun hingga kini pengaruh dari program ini masih belum secara masif bisa dirasakan, sebagaimana hasil kajian yang dilakukan oleh M. Zulfian Rahman di Balai Besar POM DIY. Selain itu, hasil kajian yang dilakukan oleh Wildan Nurul Fajar juga menggambarkan bahwa revolusi mental belum secara utuh dilakukan terutama dalam satuan pendidikan formal, mulai dari tingkat Sekolah Dasar hingga Perguruan Tinggi.

Adapun beberapa kajian lainnya yang membahas tentang revolusi mental Jokowi, secara umum dapat disimpulkan bahwa dalam implementasinya, perlu dukungan dari seluruh lapisan masyarakat. Bukan hanya pemerintah atau guru di sekolah saja, tetapi penerapan revolusi mental juga harus dilakukan secara mikro dalam skala keluarga. Selain itu nilainilai revolusi mental juga ternyata sudah terjadi dalam kehidupan pesantren, salah satunya adalah Pesantren Gontor. Hal ini tampak pada Panca Jiwa dan Motto yang menjadi ajaran turun temurun dari para pendiri pesantren, dan hingga kini masih digunakan.

Sementara itu, Syed Muhammad Naquib Al-Attas merupakan salah satu tokoh pendidikan Muslim kontemporer yang pemikirannya relevan dengan era modern ini. Gerakan Islamisasi ilmu dan purifikasi yang digalakkannya menjadikan pemikirannya memiliki ciri khas yang Islami meski tidak tertinggal oleh kemajuan zaman. Oleh karena itu peneliti ingin mengkaji konsep revolusi mental Jokowi dalam perspektif pendidikan karakter Al-Attas agar dapat diketahui konsep revolusi mental Jokowi, konsep pendidikan karakter Al-Attas, dan konsep revolusi mental 
Jokowi dalam perspektif pendidikan karakter Al-Attas. Juga kajian ini diharapkan dapat menjadi pembuka wawasan tentang pendidikan karakter, terutama pendidikan karakter Islam. Sehingga pendidikan karakter Islam tetap pada ciri khasnya dan terselamatkan dari pengaruh budaya sekularisme Barat, yang selanjutnya dapat menjadi solusi atas permasalahan yang terjadi di Indonesia.

\section{METODE PENELITIAN}

Penelitian ini adalah kualitatif dengan pendekatan filologi, agar aspek-aspek yang bersifat kesejarahan dan kebudayaan dapat ditelaah dengan baik, mengingat erat kajian ini dengan sejarah dan kebudayaan bangsa Indonesia sebagai bagian dari revolusi mental.

Jenis penelitian ini adalah studi dokumen yang menitikberatkan pada kegiatan menganalisis dan menginterpretasikan bahan literatur atau dokumen. Sumber data terdiri dari naskah resmi negara yang berkaitan dengan revolusi mental Jokowi, yaitu Inpres No. 12 Tahun 2016, Perpres No. 87 Tahun 2017, Permen PMK No. 3 Tahun 2017, Permen PMK No. 4 Tahun 2017, dan Permendikbud No. 20 Tahun 2018. Ditambah dengan bukubuku karya Al-Attas, dan buku, jurnal, artikel, serta karya ilmiah lainnya yang berkaitan. Juga beberapa rekaman wawancara eksklusif Presiden Joko Widodo yang membahas secara khusus program revolusi mental ini. Metode yang digunakan dalam pengumpulan data adalah studi pustaka dengan teknik dokumentasi. Adapun metode dan teknik dalam analisis data, peneliti menggunakan metode induktif komparatif dengan teknik analisis konten, yaitu mengumpulkan sumber data, membaca, menguasai teori, mencari dan menemukan data, menganalisis secara mendalam, dan membuat kesimpulan penelitian.

\section{HASIL DAN PEMBAHASAN}

Pada bagian ini, penulis akan menguraikan hasil penelitian dengan susunan per sub topik, yaitu:

\section{Konsep, Revolusi Mental, dan Pendidikan Karakter}

Secara etimologis, istilah konsep berasal dari kata conceptum yang berarti sesuatu yang dipahami. Menurut Kamus Besar Bahasa Indonesia, konsep adalah ide atau pengertian yang diabstrakkan dari peristiwa konkret. Ia juga berarti sebuah gambaran mental dari obyek, proses, pendapat, atau apapun yang digunakan oleh akal budi untuk memahami hal-hal lain. Dalam penelitian ini, konsep didefinisikan sebagai gambaran yang mengabstrasikan sebuah ide dalam suatu obyek.

Revolusi mental berasal dari dua suku kata yakni revolusi dan mental. Istilah revolusi pada mulanya tidak memiliki arti sebagaimana kita sekarang memaknainya. Pada abad ke-13, istilah yang kerap digunakan untuk melukiskan sebuah perubahan dasar dalam cara pandang adalah renovasi atau restorasi. Istilah revolusi baru digunakan sesudah peristiwa pemakzulan Raja Inggris tahun 1688 untuk menunjuk kepada perubahan keadaan sosial politik yang berlangsung secara cepat dan mendasar, tidak jarang diikuti dengan kekerasan. Menurut Selo Soemardjan revolusi adalah perubahan yang terjadi pada lembaga kemasyarakatan yang mempengaruhi sistem sosial dan kebudayaan, yang berkaitan dengan suatu penerimaan cara baru atau suatu perbaikan. Dari pengertian di atas, dapat disimpulkan bahwa revolusi adalah perubahan sosial dan kebudayaan yang berlangsung secara cepat dan menyangkut dasar atau pokok-pokok kehidupan masyarakat baik melalui kekerasan atau tanpa kekerasan.

Sementara mental dalam Bahasa Latin disebut dengan mens atau mentis yang artinya nyawa, roh, semangat, jiwa, dan sukma. Arti yang lain dari mental adalah batin dan watak manusia (kata benda). Dalam literatur kesehatan, mental biasanya disamakan dengan kata psikis, yang berarti jiwa. Dari beberapa pendapat tersebut, dapat diambil kesimpulan bahwa mental adalah jiwa atau watak manusia yang berkenaan dengan aktivitas berpikir dan berperasaan, di mana ia dipengaruhi oleh pengalaman, hasil belajar, dan lingkungan. 
Maka revolusi mental dapat disimpulkan sebagai perubahan cepat yang terjadi pada aktivitas jiwa (cara berpikir dan berperasaan) terkait hal-hal mendasar dalam kehidupan, yang dilakukan dengan berbagai cara untuk merobohkan sistem sosial kebudayaan lama dan membangun yang baru.

Pendidikan secara etimologi berasal dari kata didik, dan mendidik berarti memelihara atau memberi latihan. Kata pendidikan pada umumnya juga disebut dengan tarbiyah dengan asal kata kerja "rabba" yang mengandung makna pembinaan, pimpinan, pemeliharaan, dan lainnya. Secara istilah, tarbiyah dapat didefinisikan sebagai usaha, kegiatan, cara, atau alat yang digunakan untuk mengubah, membentuk, dan memperbaiki sikap mental sehingga menjadi insan kamil (utuh jasmani dan rohani). Secara lengkap, pendidikan adalah usaha penanaman nilai-nilai mulia yang secara sadar dilakukan oleh pendidik terhadap peserta didik, sehingga dapat secara aktif meningkatkan potensinya menjadi lebih baik.

Sementara karakter berasal dari bahasa Inggris, yakni character yang berarti watak, sifat, peran, akhlak, dan huruf. Karakter juga berasal dari Bahasa Yunani, charassein yang berarti mengukir. Menurut Albertus, karakter merupakan sebuah kondisi dinamis, yang tidak sekedar berhenti atas determinasi kodratinya, melainkan juga sebuah usaha untuk hidup dan mengatasi determinasi alam terhadap dirinya demi proses penyempurnaan diri. Karakter juga merupakan sekumpulan kondisi yang telah diberikan begitu saja, atau telah ada begitu saja, yang telah ada sejak lahir. Banyak tokoh Muslim yang turut mendefinisikan tentang karakter, Imam A1-Ghazali, Imam Abu A1-Fadhl, AlMawardi, Ibnu Miskawaih, Imam Al-Zarnuji, Ibnu Khaldun, dan lain sebagainya. Secara umum, para tokoh Muslim yang berlatarbelakang filosof memaknai karakter sebagai tabiat, adapun para teolog menyebut karakter dengan etika. Maka karakter merupakan sifat alami seseorang dalam merespon situasi dengan cara yang baik, berupa watak, tabiat, sikap, akhlak, kepribadian yang stabil sebagai hasil dari adanya pembinaan dan penanaman nilai-nilai kebajikan, yang menjadi landasan dalam cara memandang, bersikap, berpikir, dan bertindak.

Dari uraian di atas dapat diketahui bahwa pendidikan karakter adalah usaha internalisasi nilai-nilai kebajikan yang dengan sadar dilakukan oleh pendidik terhadap peserta didik, sekaligus pemberian benih agar peserta didik dapat secara aktif mengembangkan watak dan kepribadiannya menjadi lebih berkualitas sebagai landasan dalam cara memandang, bersikap, berpikir, dan bertindak.

\section{Konsep Revolusi Mental Presiden Joko Widodo}

Konsep revolusi mental dalam pandangan Jokowi dapat ditelusuri melalui naskah-naskah resmi pemerintah, baik itu Instruksi Presiden, Peraturan Presiden, Peraturan Menteri, dan naskah lain. Revolusi mental Jokowi meliputi lima program gerakan yang menjadi acuan utama, yakni Indonesia Melayani, Indonesia Bersih, Indonesia Tertib, Indonesia Mandiri, dan Indonesia Bersatu, untuk memperbaiki dan membangun karakter bangsa Indonesia mengacu kepada tiga nilai strategis instrumental yaitu nilai integritas, nilai etos kerja, dan nilai gotong royong. Kelima program di atas pada dasarnya bertujuan untuk membudayakan pola hidup bersih, tertib, mandiri, dan toleransi serta demokratis. Adapun Indonesia Melayani lebih diarahkan kepada pembenahan layanan publik yang selama ini dinilai kurang maksimal dan cenderung berbelit-belit.

Setidaknya ada tujuh kementerian yang berkaitan langsung dengan gerakan utama revolusi mental. Menteri Pendayagunaan Aparatur Negara dan Reformasi Birokrasi bertanggung jawab atas pelaksanaan gerakan Indonesia Melayani. Menteri Koordinator Bidang Kemaritiman bertanggung jawab atas gerakan Indonesia Bersih. Gerakan Indonesia Tertib diselenggarakan oleh Menteri Koordinator Politik, Hukum, dan Keamanan. Lalu Menteri Koordinator Bidang Perekonomian bertanggung jawab atas gerakan Indonesia Mandiri. Yang terakhir adalah gerakan Indonesia Bersatu 
yang berada di bawah tanggung jawab Menteri Dalam Negeri. Adapun bertindak sebagai koordinator dari kelima gerakan ini adalah Menteri Koordinator Bidang Pembangunan Manusia dan Kebudayaan, yang kepadanya laporan harus disampaikan paling sedikit empat bulan sekali.

Dari beberapa naskah tersebut dapat diketahui bahwa konsep revolusi mental Jokowi adalah sebuah upaya untuk mengubah cara pikir, cara kerja, cara hidup, dan sikap serta perilaku bangsa Indonesia yang mengacu pada nilai-nilai integritas, etos kerja, dan gotong royong untuk membangun budaya bangsa yang bermartabat, modern, maju, makmur, dan sejahtera berdasarkan Pancasila (18 butir karakter) yang berorientasi pada kemajuan dan kemodernan sehingga Indonesia menjadi bangsa yang besar dan mampu berkompetisi dengan bangsa-bangsa lain di dunia.

\section{Konsep Pendidikan Karakter Al-Attas}

Islam mengenal tiga istilah populer dalam menggambarkan sistem pendidikannya, yakni ta 'lim, tarbiyah, dan ta' dib. Di antara ketiganya, term tarbiyah inilah yang sering digunakan untuk merumuskan konsep pendidikan Islam, termasuk di kalangan dunia Arab. Lain halnya dengan Syed Muhammad Naquib AlAttas yang menggunakan term $t a$ 'dib dalam membahas tentang pendidikan karakter, karena menurutnya konsep tarbiyah yang selama ini merepresentasikan kata pendidikan tidaklah memberi makna yang benar.

Term tarbiyah sebenarnya merupakan istilah baru untuk merepresentasikan makna pendidikan yang muncul bersamaan dengan gerakan pembaharuan pendidikan di dunia Arab pada awal abad ke-20. Oleh karena itu tidak ditemukan dalam sumber-sumber klasik tentang term tarbiyah, tapi justru yang ada adalah ta lim, tahdzib, atau adab. Sementara Al-Attas melihat bahwa istilah tarbiyah merupakan terjemahan dari bahasa latin educare dan educatio yang dalam bahasa Inggris adalah educate. Tarbiyah dalam konotasinya dengan education berarti hanya mengacu kepada segala sesuatu yang bersifat fisik dan material saja sesuai dengan masyarakat, manusia, dan negara yang bersifat sekuler. Karena dalam kajian kitab klasik tidak ditemukan term tarbiyah dengan makna pendidikan. Kalaupun dalam istilah education juga mengandung unsur pembinaan intelektual dan moral, tapi sebagai sumbernya bukanlah wahyu melainkan hasil spekulasi tentang etika yang disesuaikan dengan tujuan fisik material orang-orang sekuler.

Istilah tarbiyah sebagaimana yang ditemukan dalam kamus bahasa Arab, berakar pada raba-yarbu yang artinya bertambah dan tumbuh. Lalu juga rabiya-yarba yang berarti berkembang, juga dari rabba-yarubbu yang berarti menguasai, memimpin, menjaga, dan memelihara. Dari ketiga akar di atas, tidak satupun yang secara alami mengandung unsur pokok pendidikan, yaitu pengetahuan, inteligensi, dan kebijakan. Selain itu, tarbiyah juga tidak terbatas pada aktivitas manusia saja, ia berlaku untuk seluruh spesies binatang dan tumbuhan. Oleh karena itu, menurut Al-Attas, tarbiyah tidak cocok untuk merepresentasikan makna pendidikan dalam arti Islam. Lebih lanjut, Al-Attas menegaskan bahwa kata tarbiyah hanya mengandung arti rahmat atau kasih sayang dan pemeliharaan.

Berikutnya adalah term ta 'lim yang juga kerap digunakan untuk menunjuk pada konsep pendidikan dalam Islam. Istilah ini terdapat dalam Al-Qur'an sebanyak 41 kali (25 fi 'il madhi dan 16 f 'il mudhari '), yang mengandung arti di antaranya informasi, nasihat, pengajaran, bimbingan, ajaran, pendidikan formal, latihan, pendidikan, dan pekerjaan magang. Menurut Abdul Fattah Jalal, term ta 'lim setidaknya mengandung dua pokok, pertama adalah proses pembelajaran yang berlangsung terus-menerus sejak manusia lahir melalui pengembangan fungsi penglihatan, pendengaran, dan hati. Kedua adalah proses tersebut tidak berhenti pada pencapaian pengetahuan saja, tapi juga sikap dan perilaku. Karena sebuah pengetahuan yang hanya sampai pada wilayah kognitif saja tidak akan mendorong seseorang untuk mengamalkan ilmunya. Melalui pendidikan seperti ini, 
Rasulullah SAW telah mengajarkan para sahabat untuk dapat mencapai tingkat penyucian diri (tazkiyah) yang selanjutnya mereka mampu mencapai tingkat al-hikmah, yang dapat membentuk kepribadian yang kokoh. Demikian pula M. Nasir Budiman yang memandang bahwa istilah ta 'lim inilah yang lebih cocok digunakan dari pada tarbiyah, di mana ta lim mencakup aspek-aspek pengetahuan dan keterampilan yang diperlukan oleh seseorang. Tapi lagi-lagi Al-Attas memandang bahwa term ta 'lim tetap tidak dapat mewakili pengertian pendidikan dalam Islam karena pemakaiannya dalam Al-Qur'an yang bersifat umum, bukan khusus manusia saja.

Selanjutnya adalah istilah $t a^{\prime} d i b$, yang dalam perumusannya mengisyaratkan bahwa pendidikan adalah adab. Menurut Al-Attas, pendidikan pada dasarnya adalah terletak pada term ta'dib yang berakar kata adaba dengan artinya sebagai mendidik, undangan perjamuan, kebudayaan, tata tertib sosial, kehalusan budi, kebiasaan yang baik, menghias, ketertiban, kepantasan, kemanusiaan, dan kesusasteraan. Sebagaimana yang dijelaskan oleh Muhammad bin Mukrim bin Ali Abu Al-Fadhl Jamaluddin Ibnu Manzhur Al-Anshari Ar-Ruwaifi'i AlAfriqi (Ibnu Mandzur 1232-1311) dengan ungkapan addabahu fa ta'addaba (mengundang seseorang dalam jamuan maka ia menjadi beradab) yang berarti mendidiknya, dengan isyarat kepada jamuan yang dipersiapkan oleh tuan rumah untuk orang-orang terhormat yang diundangnya. Para tamu undangan yang mendapat kesempatan menghadiri ini tentulah orang-orang terhormat yang tindakan dan perilakunya baik, yang kemudian menjadikan mereka diundang oleh tuan rumah. Karena pemilihan tuan rumah atas tamu yang akan diundang menggunakan pertimbangan akan kebaikan perilaku tamunya.

Selain itu, istilah $t a$ 'dib sebenarnya sudah ada sejak periode paling awal dalam sejarah Islam, sebagaimana yang ditemukan dalam hadis Nabi:

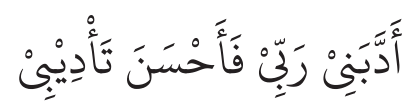

\section{"Tuhanku telah mendidikku, dan dengan demikian menjadikan pendidikanku yang terbaik"}

Hadis ini menjadi salah satu bukti bahwa term ta'dib inilah yang sesuai dengan pengertian pendidikan. Nabi Muhammad sebagai perwujudan dari kesempurnaan akhlak telah memberitakan soal ini melalui hadis tersebut. Konsep adab telah sejak awal dipahami sebagai pendidikan Islam. Bahkan saat itu, ilmu pengetahuan yang dihasilkan oleh akal manusia juga disebut dengan adab. Semua buku pada berbagai disiplin ilmu saat itu dinamakan dengan "kutub al-Adab", yang selanjutnya terkenallah kitab "Al-Adab Al-Kabir" dan "AlAdab Al-Shaghir" karangan Ibnu Al-Muqaffa (724-759). Bahkan pada saat itu, seorang ahli pendidikan dikenal dengan sebutan mu'addib. Namun pada masa Daulah Abbasiyah pengertian adab mulai mengalami pergeseran dan menjadi terbatas pada kesusasteraan saja. Hal ini terjadi ketika para ulama melakukan spesialisasi dalam bidang ilmu pengetahuan dan term adab hanya dipakai untuk ilmu akhlak atau etika. Selain itu, kekacauan dalam memahami istilah ini juga muncul akibat dari doktrin-doktrin sekularisme yang cenderung mengutamakan logika sejak masa Reneissance. Sebagai akibat dari tidak digunakannya istilah $t a$ 'dib dalam pendidikan adalah hilangnya adab dan hilangnya keadilan, yang pada gilirannya menimbulkan kebingungan serta kesalahan dalam pengetahuan.

Al-Attas menekankan bahwa pengajaran dan pengasuhan betapapun ilmiahnya tetap tidak dapat disebut dengan pendidikan jika di dalamnya tidak ada proses penanaman sesuatu yang berupa adab. Seseorang yang memiliki adab akan mampu mencegah dirinya dari kesalahan penilaian. Selanjutnya orang yang beradab akan mampu menempatkan dirinya pada posisi yang tepat pada situasi dan kondisi apa saja dengan porsi yang adil. Manusia seperti inilah yang dipandang sebagai manusia yang adil, yaitu mampu menjalankan adab pada dirinya hingga ia menjadi manusia yang baik. 
Keadilan yang dimaksud dalam konsep pendidikan karakter Al-Attas mengacu kepada penjelasannya mengenai hakikat manusia. Manusia adalah binatang rasional yang dalam bahasa Arab disebut dengan al-hayawan alnatiq. Kata natiq berarti rasionalitas yang dimiliki oleh manusia berupa akal, di samping fakultas batin yang mampu merumuskan maknamakna. Sementara "makna" yang dimaksud adalah pengakuan tempat-tempat segala sesuatu yang berada di dalam suatu sistem. Manusia dengan rasionalitasnya berfungsi sebagai khalifah di muka bumi, yang dalam konsep Al-Jamali, manusia mengenal dirinya sebagai makhluk sosial (warga negara) dan bersikap bijak terhadap alam sekitar. Sedangkan dengan fakultas batinnya, manusia berfungsi sebagai 'abdun yang dengannya ia mengenali dirinya sebagai pribadi yang berkewajiban untuk menyembah Allah.

Keadilan dalam Islam bukanlah sebuah konsep yang terjadi dalam tatanan negara yang dapat menentukan keputusan antara dua orang ataupun antarkelompok, seperti antara satu orang dengan orang lain, antara kelompok sosial dengan negara, antara pemerintah dengan rakyat, antara raja dengan pengikutnya. Lalu, apakah seseorang dapat berbuat tidak adil terhadap dirinya sendiri? Inilah konsep keadilan dalam Islam, yang bahkan ketika seorang manusia tidak melakukan apa yang seharusnya dilakukan (sebagaimana fungsi manusia) sebenarnya termasuk tindakan yang tidak adil.

Manusia adil adalah yang memberikan porsi yang sesuai terhadap fakultas batin dan aspek rasionalitasnya. Maksud porsi yang sesuai di sini adalah bahwa fakultas batin hendaklah mengakui tempat-tempat yang tepat akan segala sesuatu, yang selanjutnya akan mengakui tempat yang tepat bagi Sang Pencipta. Jika demikian, seorang manusia akan menjadi insan kamil yang senantiasa menjalankan perintah Allah dan menjauhi larangan-Nya, termasuk dalam urusan tata sosial. Dengan begitu dia juga telah menjalankan fungsinya sebagai khalifah, sebagaimana yang telah dijelaskan mengenai kepribadian Rasulullah SAW sebagai prototipe dalam konsep insan kamil. Fungsi khalifah karena manusia telah diberikan kekuasaan oleh Allah untuk menjalankan "pemerintahan" (mengatur dirinya) sesuai keinginan Allah. Sebaliknya, jika seorang manusia hanya mengandalkan fakultas rasionalnya saja untuk menjalankan fungsinya sebagai khalifah, belum tentu ia akan mampu menjalankan fungsinya dengan baik sebagai 'abdun. Maka dalam konsep pendidikan karakternya, AlAttas tidak menjadikan negara sebagai standar pendidikannya, tetapi lebih kepada mencetak manusia yang adil.

Penekanan Al-Attas terhadap aspek adab sebagaimana uraian di atas menerangkan bahwa ilmu pengetahuan yang diperoleh seseorang hendaklah diamalkan secara baik dan tidak disalahgunakan. Karena ilmu tidaklah bebas nilai (value free) melainkan sarat akan ilmu (value laden), di mana nilai-nilai Islami menghendaki pemiliknya untuk mengamalkan ilmu tersebut demi kemaslahatan umat manusia. Oleh karena itu, istilah $t a$ ' dib juga mengarahkan kepada konsep ilmu dan amal yang dalam penjelasannya digunakan istilah pengenalan, hingga menjadi manusia yang sempurna (insan kamil). Karena ilmu tanpa amal adalah sebuah kecongkakan, dan amal tanpa adanya ilmu merupakan sebuah kejahilan. Dengan demikian dapat disimpulkan bahwa istilah ta'dib telah mengandung unsur pengajaran ( $\mathrm{ta}$ ' lim) dan pengasuhan (tarbiyah). Sehingga tidaklah penting menggabungkan istilah di atas ke dalam konsep ta'dib, karena telah mencakup keduanya.

Pembagian ilmu yang dilakukan oleh Al-Attas, ilmu fard 'ain dan fard kifayah, memberikan isyarat bahwa fakultas batin manusia hendaklah lebih diprioritaskan dari pada sisi rasionalitasnya. Hal ini terlihat dari sikap kewaspadaannya terhadap pengaruh budaya sekularisme Barat yang dewasa ini telah banyak diadopsi sebagai landasan dalam sistem pendidikan. Fakultas rasional manusia yang melahirkan ilmu terapan (ilmu rasional, intelektual, dan filosofis) dalam klasifikasi ilmu Al-Attas tidaklah dikategorikan dalam ilmu fard 
'ain atau wajib. Selain itu, ilmu-ilmu tersebut hendaklah terlebih dahulu dilakukan Islamisasi, yaitu dibersihkan dari pengaruh Barat dan diresapi dengan ajaran Islam.

Secara lengkap, konsep pendidikan karakter menurut Al-Attas sebagaimana dirumuskan dari beberapa unsur kunci di atas yaitu pengenalan dan pengakuan, yang secara berangsur-angsur ditanamkan di dalam manusia, tentang tempat-tempat yang tepat dari segala sesuatu di dalam tatanan penciptaan sedemikian rupa, sehingga membimbing ke arah pengenalan dan pengakuan tempat Tuhan yang tepat di dalam tatanan wujud dan keperiadaan.

Dari uraian di atas, tampak bahwa konsep pendidikan karakter Al-Attas berbeda dengan konsep pendidikan karakter yang diuraikan pada bab sebelumnya. Agaknya konsep Al-Attas tampak sederhana karena menggunakan istilah yang diulang-ulang. Tapi pada hakikatnya, menurut Imam Bawani pemilihan kata tersebut justru menunjukkan kesan abstrak dan filosfis yang tinggi. Konsep Al-Attas tidak terlalu memperhatikan unsur-unsur praktis yang pada era modern ini malah dinilai penting. Ini menunjukkan bahwa pemikiran Al-Attas tidak terpengaruh oleh ide-ide sekuler Barat yang saat ini diikuti oleh banyak tokoh pendidikan.

\section{Sejarah Revolusi Mental}

Revolusi mental bukanlah barang baru dalam perjalanan sejarah Republik Indonesia. Meskipun pada dekade kedua abad ke-21 ini revolusi mental berhasil dipopulerkan kembali oleh Presiden Joko Widodo hingga menjadi jargon utamanya saat kampanye pemilihan presiden tahun 2014. Menurutnya, revolusi mental adalah sebuah keniscayaan, di mana seluruh warga Indonesia mengerti, memahami, dan mengenal karakter asli bangsa.

Namun kenyataannya, kian hari karakter justru berubah dan mengalami dekadensi yang tak terelakkan. Inilah yang sebenarnya menjadi akar terjadinya tindak pidana korupsi, kolusi, nepotisme, rusaknya birokrasi, buruknya etos kerja, hingga ketidakdisiplinan dalam bekerja. Dengan melihat kondisi bangsa yang begitu memprihatinkan, kehadiran gagasan revolusi mental menjadi angin segar bagi bangsa Indonesia yang saat ini tengah rindu akan kemajuan.

Di lain pihak, program revolusi mental justru dipandang sebelah mata oleh beberapa kalangan. Banyak yang memaknai kata revolusi sebagai perubahan yang cepat dan radikal. Hal ini terjadi mungkin karena memori lama tentang peristiwa Revolusi Kebudayaan di Cina, atau Revolusi Perancis, hingga Revolusi Rusia yang menggambarkan bahwa revolusi dilakukan secara radikal, berdarah-darah, menyebabkan banyak korban, memberikan luka mendalam, dan penuh dengan kekerasan serta penyiksaan.

Dengan jargon revolusi mental ini, Jokowi dinilai beraliran kiri dan mengikuti paham sosialis komunis. Di antara faktor penyebab justifikasi negatif terhadap Jokowi tersebut adalah adanya indikasi untuk membuat pembagian dua kelompok besar dalam tatanan masyarakat Indonesia, sebagaimana yang dinyatakan oleh Prof. Dr. Zainudin Maliki (Ketua Dewan Pendidikan Jawa Timur dan Rektor Universitas Muhammadiyah Surabaya). Kelompok atas yang terdiri dari agama, pendidikan, dan hukum, serta kelompok bawah yaitu hubungan borjuis dengan kaum proletar.

Dr. H. Fadli Zon, wakil ketua Dewan Perwakilan Rakyat (DPR) Republik Indonesia periode 2014-2019, yang juga seorang politisi partai Gerakan Indonesia Raya (Gerindra) turut memandang bahwa revolusi mental Jokowi mengikuti aliran filosof Jerman, Karl Marx (1818-1883) yang juga dipengaruhi oleh pemikiran seorang filosof atheis bernama Georg Wilhelm Friedrich Hegel (1770-1831) di Berlin, Jerman. Penganut paham sosialis komunis memandang bahwa revolusi mental sangatlah penting bagi perjuangan mereka. Revolusi mental yang diajarkan oleh leluhur mereka, Karl Marx bertujuan untuk mengubah mental rakyat yang saat itu tengah terbius oleh agama dan mengatakan bahwa agama adalah the opium of the masses. Agama dijadikan sebuah media untuk mengelabui rakyat dan menutupi kegagalan penguasa dalam mengelola 
negara, sehingga rakyat lupa akan penderitaan dan kesengsaraan mereka. Kondisi inilah yang membuat Marx menggerakkan massa dengan ide revolusi mental untuk segera mengadakan perlawanan terhadap pemerintah. Inilah poin utama dalam revolusi mental yang digagas oleh penganut sosialis komunis untuk berani menuntut haknya kepada negara.

Negara dan agama adalah musuh besar bagi rakyat atau kaum proletar. Sehingga negara yang tidak menganut paham komunis dinilai justru akan menyengsarakan rakyat. Demikian halnya agama yang hanya menjadi media kebohongan untuk mengelabui rakyat hingga lupa akan kegagalan pemerintah dalam melaksanakan tugasnya. Untuk itu, kedua musuh tersebut haruslah dilawan dan dihilangkan. Negara harus dikuasai untuk selanjutnya dijadikan negara komunis. Di sini, mental yang kuat sangatlah dibutuhkan untuk merealisasikannya. Itulah sebabnya mengapa revolusi mental menjadi sangat strategis untuk menanamkan keyakinan kepada rakyat. Melalui sebuah perubahan dalam lingkungan sosial, maka mental dan karakter manusia akan dapat terbentuk. Manusia dipandang hanya sebagai objek yang mental atau karakternya dibentuk melalui perubahan lingkungan sosialnya, dan unsur subjektivitas tidaklah memberikan pengaruh signifikan terhadap perubahan mental individu.

Jika benar bahwa revolusi mental Jokowi terinspirasi dari ajaran sosialis komunis, maka mental atau karakter bangsa Indonesia, sebagaimana pandangan paham ini, hanya akan terbentuk karena pengaruh lingkungan. Dalam hal ini, watak dan faktor hereditas tidaklah memberikan pengaruh yang nyata terhadap perubahan karakter bangsa. Sehingga dalam proses pelaksanaan program revolusi mental ini, haruslah berorientasi pada perubahan lingkungan secara total, baik struktur maupun kultur, meski harus menghilangkan peran agama dalam merealisasikannya.

Namun, meski beberapa pandangan menilai bahwa revolusi mental Jokowi beraliran kiri dan kental dengan ajaran sosialis komunis, tetap saja bukti dan argumen yang diajukan tidaklah begitu kuat. Sikap penolakan mereka cenderung bernuansa politis. Jika menelusuri ajaran dari aliran non-sosialis komunis (aliran kanan), revolusi mental relevan dengan paham liberalis kapitalis. Salah seorang tokoh aliran kanan ini adalah Max Weber (1864-1920), pakar sosiologi asal Jerman yang ajarannya banyak mengkritisi paham Karl Marx. Pemikiran Weber tentang sosiologi membawa dampak yang sangat besar terhadap perkembangan ilmu sosiologi di dunia. Weber berfokus pada gagasan dan nilai sosiologis yang dapat menjadi alternatif dalam cara berpikir, sekaligus menjadi kritik tajam bagi paham Marxsisme yang sosialis komunis. Karena paham sosialis komunis memiliki tendensi untuk selalu berusaha menghilangkan aspek spiritual dari diri manusia.

Secara singkat, pemikiran Weber tentang tindakan manusia terbagi menjadi empat tipe. Pertama adalah rasional instrumental yaitu tindakan yang dilakukan oleh manusia dengan dilandasi rasionalitas demi sebuah tujuan. Tipe kedua yaitu rasional nilai yang mengacu pada tindakan yang didasari oleh kepercayaan terhadap ajaran tertentu. Ketiga yakni tipe afeksi, mengacu kepada tindakan yang dilandasi oleh perasaan seorang individu. Tipe keempat adalah tradisional, di mana tindakan didasari oleh tradisi atau kebiasaan yang sering dilakukan sejak nenek moyang manusia.

Melalui salah satu karya monumentalnya yang berjudul Basic Sociological Terms, Weber menjelaskan bahwa setiap tindakan individu terhadap individu atau kelompok lainnya adalah bersifat subjektif. Fokus kajian sosiologinya adalah kepada tindakan sosial masyarakat, yang pada gilirannya sosiologi dapat memahami dan menjelaskan secara mendalam tentang makna subjektif dari fenomena sosial tersebut. Subjektif di sini melihat bahwa mental dan karakter manusia terbentuk dengan adanya niat subyektif aktor. Dengan demikian, aspek subjektivitas kejiwaan seseorang memiliki porsi yang sangat besar untuk melakukan sebuah perubahan terhadap dirinya sendiri. Kondisi psikologis dengan tingkatannya yang berbeda pada setiap orang tersebut membutuhkan selalu 
membutuhkan peran agama untuk kebutuhan penentraman yang bermanfaat. Sehingga, ambivalensi atau ketiadaan norma-norma religius yang sering terjadi merupakan sebuah masalah dan tantangan yang baru.

Mengacu kepada uraian di atas, revolusi mental Jokowi tampaknya juga memiliki kesamaan dengan ajaran Weber, meski tidak bisa dipastikan apakah ada keterkaitan di antara keduanya. Revolusi mental Jokowi, sebagaimana yang tercantum di dalam naskah resmi negara, tidak hanya sekedar untuk perubahan karakter secara cepat. Gagasan ini bertujuan untuk membangkitkan kesadaran diri dan membangun sikap optimis dalam menatap masa depan Indonesia sebagai negara besar sehingga menjadi bangsa yang maju dan modern.

Dalam konteks historisitas Indonesia, pada awal munculnya jargon revolusi mental Jokowi ini, presiden Indonesia ke-7 tersebut dipandang mengikuti jejak Partai Komunis Indonesia (PKI). PKI yang didirikan pada tahun 1920 dan sejak tahun 1948 semakin gencar menyebarkan paham komunis itu sering menggunakan jargon revolusi mental untuk menuju Indonesia yang maju dan sejahtera. Di bawah kepemimpinan Dipa Nusantara Aidit (1923-1965), revolusi mental PKI menjadi sebuah langkah strategis untuk mengubah mental rakyat Indonesia yang terganggu oleh dogma agama. Meski sebenarnya sikap penolakan PKI terhadap eksistensi Islam Indonesia tidaklah sama persis dengan ajaran komunisme Marx yang menolak kehadiran agama sepenuhnya.

Tan Malaka (1897-1949) salah seorang pemimpin komunis Indonesia percaya bahwa Islam dapat digunakan untuk meraih cita-cita revolusioner. Demikian juga tokoh lain seperti Haji Mohamad Misbach (1876-1926) dan Haji Tubagus Achmad Chatib (1885-1966) yang meyakini bahwa tidak ada perbedaan fundamental antara Islam dan Komunis. Secara umum gagasan Aidit dalam mengembangkan PKI mengadopsi ajaran-ajaran sosialis komunis yang diperkenalkan oleh Marx.

Presiden pertama Republik Indonesia, Soekarno (1901-1970) juga termasuk salah seorang tokoh yang kerap menggunakan istilah revolusi mental. Salah satunya adalah dalam pidato saat peringatan hari Proklamasi Republik Indonesia pada 17 Agustus 1962 dengan tema Tahun Kemenangan. Soekarno menjelaskan bahwa revolusi mental bertujuan untuk menggembleng manusia agar berhati putih, berkemauan baja, bersemangat elang rajawali, berjiwa api menyala-nyala. Pada substansinya, makna yang terkandung dalam gagasan itu adalah transformasi etos, yakni perubahan mendasar dalam mentalitas, semangat dan moralitas, termasuk juga cara berfikir, cara merasa, dan cara mempercayai, yang menjelma ke dalam perilaku dan tindakan sehari-hari. Lebih luas lagi, Soekarno merefleksikan gagasan revolusi mental dalam konsep Trisaktinya, yaitu berdaulat secara politik, mandiri secara ekonomi, dan berkepribadian dalam kebudayaan.

Namun lagi-lagi, Soekarno juga dipandang beraliran kiri sebagaimana PKI karena sikapnya yang menganakemaskan kelompok komunis di antara partai-partai yang ada pada masa Demokrasi Terpimpin. Hal ini didasari oleh keadaan saling membutuhkan dan memerlukan antara Soekarno dan PKI, serta posisi Soekarno yang anti-Barat karena keputusannya untuk menarik Indonesia dari keanggotaan PBB akibat politik konfrontasi Malaysia. Partai lainnya yang juga beraliran kiri adalah Partai Nasional Indonesia (PNI) yang didirikan oleh Soekarno pada tahun 1927 dan Partai Syarikat Islam Indonesia (PSII) dengan tokohnya Haji Agus Salim yang memandang bahwa kapitalisme harus dihilangkan. Inilah yang terjadi di Indonesia, di mana sebagian besar partainya secara ideologis beraliran kiri kecuali Partai Masyumi yang alirannya cenderung mendekati liberal.

Demikianlah sejarah munculnya istilah revolusi mental yang memang telah ada sejak abad pertengahan, dan hingga kini di Indonesia masih sering digunakan. Secara umum respon tersebut terbagi menjadi dua sikap, yaitu menolak secara historis dan menerima secara substantif. Hal ini karena istilah revolusi mental telah banyak dan sering digunakan dalam dialektika perjalanan sejarah pemikiran, 
manajemen, politik, sosial, baik di dunia Barat maupun Timur.

\section{Perbandingan Konsep}

Bagian ini akan menguraikan masingmasing konsep agar dapat diketahui unsurunsur penting yang ada di dalamnya dengan standar atau pilar pendidikan yang dirumuskan oleh UNESCO (United Nations Educational, Scientific, and Cultural Organization), yaitu empat pilar; learn to know, learn to do, learn to live together dan learn to be. Alasan penggunaan empat pilar tersebut adalah karena relevansinya dengan konsep pendidikan pada umumnya, terutama di Indonesia sebagai negara majemuk dan multikultur, yang meski ada kurikulum nasional juga tetap mengakomodir materi kearifan lokal. Adapun sistem pendidikan di Indonesia sementara ini mengikuti teori pakar psikologi Benjamin Samuel Bloom (1913-1999) dalam mengklasifikasikan tingkat perkembangan pendidikan anak secara obyektif, sebagaimana yang dianut oleh mayoritas negara-negara di dunia dalam perumusan tujuan, penyusunan tes, dan pembuatan kurikulum. Klasifikasinya yang biasa disebut dengan taksonomi Bloom ini terdiri dari tiga butir, yaitu kognitif, afektif, dan psikomotorik.

Di sini terjadi perbedaan mendasar antara teori yang dirumuskan oleh Bloom yakni tiga butir taksonomi hierarkisnya dengan empat pilar pendidikan UNESCO. Setidaknya secara jumlah keduanya tampak berbeda, yang disebut pertama berjumlah tiga butir dan yang kedua empat butir. Oleh karena itu, penulis memandang perlunya dilakukan upaya untuk merumuskan sebuah teori baru sehingga dapat mengurangi atau menambah, atau justru menggabungkan antara keduanya.

Learning to know sesuai dengan aspek kognitif dalam taksonomi Bloom. Learning to do memiliki makna yang sama dengan aspek psikomotorik. Adapun Learning to live together, melihat ranahnya yang mengarah kepada sikap, maka termasuk dalam aspek afektif. Yang terakhir adalah learning to be. Istilah ini yang dalam taksonomi Bloom tidak mendapatkan tempat yang tepat di antara ketiga aspek. "To be" tidaklah dapat diwakili dengan kognitif, psikomotorik, ataupun afektif. Ia lebih cenderung kepada hal-hal yang bersifat harapan, keinginan, dan cita-cita. Untuk itu, penulis menggunakan istilah teleologis, meminjam istilah dari M. Syifa A. Widigdo, yang berasal dari akar kata bahasa Yunani telos (tujuan dan maksud) untuk menggantikan pilar tersebut.

Berdasarkan keempat standar di atas, penulis akan membandingkan konsep revolusi mental Jokowi dengan pendidikan karakter AlAttas. Pertama adalah ranah kognitif mencakup ingatan atau pengenalan terhadap fakta-fakta tertentu, pola-pola prosedural, dan konsepkonsep yang memungkinkan berkembangnya kemampuan dan skil intelektual. Dengan demikian, tampak bahwa konsep revolusi mental Jokowi secara eksplisit memberikan perhatian terhadap aspek ini meski hanya sepintas, di mana terdapat ungkapan pengubahan "cara pikir" yang mewakili aspek kognitif. Demikian halnya dengan Al-Attas yang juga memberikan penekanan terhadap aspek intelektual, yang dalam konsepnya digunakan istilah "pengenalan". Al-Attas menjelaskan bahwa "pengenalan" yang dimaksud sama artinya dengan istilah ta 'allum yang berarti belajar. Selain itu "pengenalan" merupakan sebuah aktivitas di mana seseorang menggunakan kemampuan berpikirnya untuk mengetahui sesuatu.

Kedua adalah ranah psikomotorik yang berkaitan dengan kegiatan-kegiatan manipulatif atau keterampilan motorik. Di sini, konsep revolusi mental Jokowi memberikan perhatian yang besar agar negara Indonesia mampu menjadi bangsa yang mampu berkompetisi dengan bangsa-bangsa lain di dunia. Sementara Al-Attas, penggunaan istilah "pengenalan" yang mengacu kepada konsep ilmu dan amal, menunjukkan keluasan perhatiannya terhadap aspek psikomotorik. Secara bahasa agaknya istilah "pengenalan" tidak berkaitan dengan perbuatan atau aspek psikomotorik. Al-Attas tidak membedakan secara khusus antara aspek kognitif dan psikomotorik, karena memang 
konsepnya tentang pendidikan karakter tidak terpengaruh oleh pemikiran Barat yang dinilainya sekuler. Namun dalam konsepnya tentang ilmu dan amal, ia menegaskan bahwa sebuah ilmu tidaklah berarti tanpa adanya pengamalan. Menurutnya, ilmu tanpa pengamalan berarti sebuah kecongkakan, dan amal tanpa adanya ilmu berarti sebuah kejahilan. Maka dengan mengacu kepada konsep ilmu dan amal tersebut, istilah "pengenalan" dapat diartikan pula dengan aspek psikomotorik.

Ketiga adalah ranah afektif yang berkaitan dengan perkembangan perasaan, sikap, nilai, dan emosi. Pada ranah ini pula Jokowi memberikan perhatian yang besar dalam konsep revolusi mentalnya. Beberapa istilah yang secara jelas tersebut dalam konsep tersebut adalah "cara hidup dan sikap yang berpedoman pada nilai integritas dan gotong royong". Demikian pula Al-Attas, perhatiannya terhadap aspek afektif tampak pada penggunaan istilah "pengakuan". Mengakui, dalam kamus bahasa Indonesia berarti menyatakan sah atau menyatakan berhak. Pemilihan kata yang dilakukan oleh Al-Attas bersifat global. Ini berarti bahwa, setelah melalui tahap pengenalan (kognitif dan psikomotorik), seorang manusia hendaklah meningkatkan dirinya kepada tingkat pengakuan (afektif) yang terjadi di dalam fakultas batinnya.

Keempat adalah aspek teleologis, atau yang berarti tujuan. Konsep revolusi mental Jokowi bertujuan untuk mendidik peserta didik menjadi warga negara yang baik. Hal ini tampak secara eksplisit dalam konsepnya yang berbunyi "berorientasi pada kemajuan dan kemodernan sehingga Indonesia menjadi bangsa yang besar". Lain dengan Al-Attas, ia tidak menjadikan sebuah negara sebagai patokan dalam perumusan konsep pendidikan karakternya, melainkan kepada ajaran agama Islam. Sehingga dalam konsepnya ia menyatakan "membimbing ke arah pengenalan dan pengakuan tempat Tuhan yang tepat di dalam tatanan wujud dan keperiadaan". Pengenalan dan pengakuan tempat Tuhan yang tepat merupakan susunan kata yang bersifat umum. Namun jika dicari kata yang mungkin dapat mewakilinya, kata tersebut adalah "keadilan". Istilah keadilan dalam Islam merupakan antonim dari kezaliman, yang memiliki arti meletakkan sesuatu pada tempatnya. Dari sini dapat disimpulkan bahwa aspek teleologis dari konsep pendidikan karakter Al-Attas adalah menjadikan peserta didik sebagai orang yang adil. Keadilan sebagaimana dijelaskan sebelumnya, mengacu kepada penjelasan Al-Attas mengenai hakikat manusia.

\section{Konsep Revolusi Mental Jokowi dalam Perspektif Pendidikan Karakter Al-Attas}

Konsep revolusi mental Presiden Joko Widodo sebagaimana telah disinggung pada pembahasan terdahulu, merupakan gagasan yang menjadi angin segar bagi bangsa Indonesia. Namun di lain sisi, banyak kalangan yang justru menilai revolusi mental Jokowi merupakan gerakan "kiri”" yang diadopsi dari paham sosialis komunis. Revolusi mental memang bukanlah hal baru yang memang baru digunakan oleh Jokowi untuk gerakannya. Secara historis, revolusi mental Jokowi memiliki kesamaan dengan aliran komunis. Namun secara substantif revolusi mental Jokowi berbeda dengan ajaran komunis, dan justru memiliki orientasi yang sejalan dengan aliran non-kiri.

Dalam perspektif pendidikan karakter Al-Attas, konsep revolusi mental Jokowi sedikit mengandung perbedaan lantaran landasan yang digunakan tidaklah sama. Al-Attas melandasi pemikirannya tentang pendidikan karakter hanya dengan ajaran agama Islam, lain halnya dengan Jokowi yang menjadikan wawasan kebangsaan sebagai dasar dalam merumuskan konsep revolusi mentalnya, meski tidak meniadakan peran agama.

Dengan menggunakan empat standar (4 pilar UNESCO) untuk membandingkan konsep revolusi mental Jokowi dan pendidikan karakter Al-Attas, peneliti menemukan beberapa perbedaan di antara keduanya. Dari aspek kognitif, konsep revolusi mental Jokowi hanya memberikan perhatian yang kecil, sementara AlAttas memberikan penekanan yang seimbang dengan aspek psikomotorik. 
Dalam aspek psikomotorik, revolusi mental Jokowi memberikan perhatian yang besar di samping aspek afektif, karena memang inilah fokus dari gerakannya. Lain dengan AlAttas yang menempatkan aspek psikomotorik seimbang dengan kognitif, dan menekankan kepada aspek afektif. Hal ini dilakukan karena Al-Attas melihat jika seorang manusia telah menduduki posisi "pengakuan" tentu ia telah melalui tahapan "pengenalan" yang itu menjadi prasyarat dari yang disebut pertama. Sehingga penekanan Al-Attas kepada aspek afektif bersifat hierarkis.

Adapun pada aspek terakhir, yaitu teleologis, terjadi perbedaan yang fundamental antara keduanya, di mana revolusi mental bertujuan untuk mencetak warga negara yang baik, sementara Al-Attas mencitakan terbentuknya seorang insan kamil.

Hasil uraian tentang empat aspek di atas menjadi landasan bagi peneliti untuk dapat melakukan peninjauan terhadap konsep revolusi mental Jokowi dari perspektif pendidikan karakter Syed Muhammad Naquib Al-Attas. Setidaknya ada dua poin yang menjadi hasil penelitian ini.

Pertama adalah bahwa konsep revolusi mental Jokowi memberikan penekanan utamanya kepada aspek psikomtorik dan afektif, yang nyaris mengabaikan aspek kognitif. Bahkan dalam beberapa wawancara eksklusif yang membahas tentang revolusi mental, Jokowi hampir tidak pernah membahas unsur kognitif ini. Jokowi hanya fokus terhadap pembangunan manusia dari sisi afektif dan psikomotorik untuk membangun karakter bangsa dan keterampilan serta etos kerja agar Indonesia mampu bersaing dengan negara-negara lainnya. Karena memang saat ini negara Indonesia sedang mengalami dekadensi moral dan membutuhkan perubahan terutama pada aspek sikap. Selain itu daya saing bangsa Indonesia dalam dunia internasional, sebagaimana survei oleh UNDP dan PISA, dinilai masih rendah dan keterampilan serta etos kerja perlu terus dikembangkan.

Sedangkan dalam pemikiran pendidikan karakter, Al-Attas memberi penekanan terhadap aspek afektif dengan istilah "pengakuan", dengan tetap menjadikan "pengenalan" sebagai satu syarat untuk menduduki level "pengakuan". Oleh karena itu, penekanan AlAttas terhadap aspek afektif "pengakuan" yang terjadi dalam fakultas batin manusia, tidak serta merta mengabaikan aspek kognitif dan psikomotorik. Kedua aspek yang diistilahkan dengan "pengenalan" tersebut bersifat hierarkis yang tentu telah dilalui tatkala seorang manusia sudah masuk ke ranah "pengakuan".

Poin kedua adalah bahwa konsep revolusi mental Jokowi mencitakan upayanya untuk mencetak warga negara yang baik. Lain halnya dengan pandangan pendidikan karakter Al-Attas, menjadi warga negara yang baik saja tidaklah cukup. Hendaknya juga ditanamkan nilai-nilai keagamaan yang kelak akan membimbing manusia menjadi orang yang adil, di mana fakultas batin atau aspek afektif menjadi prioritas di samping aspek rasional atau akal manusia. Bukan untuk menomorduakan peran aspek rasional (ilmu dan amal), sebagaimana dijelaskan sebelumnya, tetapi aspek rasional menjadi prasyarat tercapainya fakultas batin. Dengan demikian, seorang manusia akan mampu menempatkan segala sesuatu pada tempatnya yang tepat, sesuai dengan pertimbangan yang terjadi di dalam fakultas batinnya.

Dalam Islam, fungsi penciptaan manusia ada dua, yaitu fungsi 'abdun dengan kewajibannya beribadah kepada Allah SWT dan fungsi khalifah dengan tugasnya sebagai pengelola atas bumi ini. Demikian halnya pendidikan karakter Al-Attas yang mementingkan fungsi 'abdun (afektif) untuk menjadikan manusia sebagai insan kamil yang senantiasa menjalankan seluruh kewajibannya kepada Allah dan meninggalkan laranganNya. Dengan itu seorang manusia juga telah menjalankan fungsinya sebagai khalifah atau warga negara dengan baik. Tetapi warga negara yang baik (khalifah) belum tentu akan menjadi insan kamil yang dapat mengendalikan fakultas batinnya untuk selalu berbuat adil dan menempatkan segala sesuatu pada tempatnya yang tepat. 
Melihat penjelasan di atas, penulis menyimpulkan bahwa konsep revolusi mental Jokowi jika ditinjau dari konsep pendidikan karakter Al-Attas berada pada posisi ta'dib untuk menjadi khalifah. Adapun Al-Attas, konsep ta'dib yang dicanangkannya bertujuan untuk menjadi 'abdun yang baik hingga terciptalah sosok insan kamil. Di samping itu perbedaan juga terjadi pada penekanan revolusi mental terhadap aspek afektif dan psikomotorik yang hampir mengabaikan aspek kognitif, sementara Al-Attas mengutamakan aspek afektif (fakultas batin) dan menempatkan aspek lainnya secara hierarkis.

\section{KESIMPULAN}

Dari pembahasan di atas, dapat disimpulkan dua hal, pertama adalah konsep revolusi mental Presiden Joko Widodo jika ditinjau dari perspektif pendidikan karakter Syed Muhammad Naquib Al-Attas menduduki konsep ta'dib pada level untuk menjadi khalifah. Kedua, perbedaan juga terjadi pada penekanan revolusi mental terhadap aspek afektif dan psikomotorik serta hampir mengabaikan aspek kognitif, sementara Al-Attas mengutamakan aspek afektif yang hierarkis dalam pendidikan karakternya.

\section{DAFTAR PUSTAKA}

Afifuddin dan Beni Ahmad Saebani. 2009. Metodologi Penelitian Kualitatif. Bandung: Pustaka Setia.

Anas, Azwar, dkk. 2014. Jokowi, Sosok Satrio Piningit?. Yogyakarta: Citra Media Pustaka.

Al-Attas, Syed Muhammad Naquib. 1981. Islam dan Sekularisme. Terj. Karsidjo Djojosuwarno. Bandung: Penerbit Pustaka.

—_- 1990. Islam dalam Sejarah dan Kebudayaan Melayu. Bandung: Percetakan Mizan. 1992. Konsep Pendidikan dalam Islam. Terj. Haidar Bagir. Bandung: Percetakan Mizan.

2001. Risalah untuk Kaum Muslimin. Kuala Lumpur: ISTAC.
2013. Islam: The Concept of Religion and The Foundation of Ethics and Morality. Malaysia: Percetakan Mesbah Sdn.

Albertus, Doni Koesoema. 2012. Pendidikan Karakter, Strategi Mendidik Anak di Zaman Global. Jakarta: PT Grasindo.

Al-Ghazali, Abu Hamid Muhammad Bin Muhammad. Ihya 'Ulum al-Din. Jilid I. Semarang: PT Karya Toha Putra.

Al-Mawardi, Abu al-Hasan Ali Bin Muhammad Bin Habib. 1299. Adab al-Dunya Wa alDin. Konstantinopel: Jawaib Press.

Al-Shafi'i, Mohammed Muneer'deen Olodo, dkk. 2019. Ethical Perceptions and Relationship in Islam: A Textual Abridged Summary of Al-Ghazali's View. Journal of Legal, Ethical and Regulatory Issues. Vol. XXII No. II. University of Sultan Zainal Abidin.

Arifin, Muhammad. 1986. Ilmu Perbandingan Pendidikan. Jakarta: Golden Terayon Press.

Arifin, Zaenal. 2002. Moralitas Al-Qur'an dan Tantangan Modernitas. Semarang: Gama Media.

Aristyasari, Yunita Furi. 2013. Pemikiran Pendidikan Islam Syed Muhammad Naquib Al-Attas. Jurnal Kajian Islam Interdisipliner. Vol. XIII No. II, JuliAgustus. Yogyakarta: UIN Sunan Kalijaga. Asrori, Muhammad Abdul Roziq. 2016. Peran Pendidikan Karakter Melalui Revolusi Mental untuk Membangun Generasi Bangsa. Jurnal Rontal Keilmuan PPKn. Vol. II No. II, November 2016.

- 2017. Perwujudan Nilai-Nilai Strategis Revolusi Mental Pendidikan pada Kearifan Lokal Pesantren. Jurnal Civics. Vol. XIV No. I, Mei 2017. STKIP PGRI Tulungagung.

Badaruddin, Kemas. 2007. Filsafat Pendidikan Islam (Analisis Pemikiran Syed Muhammad Naquib Al-Attas. Yogyakarta: Pustaka Pelajar.

Bakker, Anton dan Ahmad Charis Zubakir. 1990. Metodologi Penelitian Filsafat. Jakarta: Kanisius. 
Barnawi dan Jajat Darojat. 2018. Penelitian Fenomenologi Pendidikan, Teori dan Praktik. Yogyakarta: Ar-Ruzz Media.

Barnawi dan M. Arifin. 2016. Strategi dan Kebijakan Pembelajaran Pendidikan Karakter. Yogyakarta: Ar-Ruzz Media.

Bawani, Imam. 1987. Segi-segi Pendidikan Islam. Surabaya: Al-Ikhlas.

Budiman, M. Nasir. 1999. Ilmu Pendidikan II. Banda Aceh: Ar-Raniry Press.

Camenka, Eugene. 1952. The Concept of a Political Revolution: A World in Revolution. London: Secker.

Cawidu, Harifudin. 1991. Konsep Kufr dalam Al-Qur'an: Suatu Kajian Teologis dengan Pendekatan Tematik. Jakarta: Bulan Bintang.

Darmawan, I Putu Ayub dan Edy Sujoko. 2013. Revisi Taksonomi Pembelajaran Benyamin S. Bloom. Jurnal Satya Widya. Vol. XXIX No. I, Juni 2013. Universitas Kristen Satya Wacana.

Daud, Wan Mohd Nor Wan. 2003. Filsafat dan Praktik Pendidikan Islam Syed M. Naquib Al-Attas. Bandung: Mizan Pustaka.

Delors, Jacques, et.al. 1996. Learning: The Treasure Within. Report to UNESCO of the International Commissions on Education for the Twenty-fisrt Century. France: UNESCO Publishing.

Dermawanti dkk. 2015. Faktor-Faktor yang Mempengaruhi Kriminalitas di Kabupaten Batang dengan Analisis Jalur. Jurnal Gaussian. Vol. IV No. II. Universitas Diponegoro.

Diniah, Hikmah. 2007. Gerwani Bukan PKI. Yogyakarta: Penerbit Carasvati Books.

El-Quussy, Abdul Aziz. 1974. Pokok-Pokok Kesehatan Mental. Terj. Zakiyah Daradjat. Jakarta: Bulan Bintang.

Fajar, Wildan Nurul. 2018. Pelaksanaan Revolusi Mental di Indonesia: Kajian dalam Konteks Pendidikan Kewarganegaraan. Jurnal Ilmiah Kependidikan. Vol. XI No. II, Maret 2018. FKIP Universitas Muhammadiyah Purwokerto.
Garner, Bryan A. 1999. Black's Law Dictionary. St. Paul: West Group.

Gunawan, Heri. 2012. Pendidikan Karakter: Konsep dan Implementasi. Bandung: Alfabeta.

Gunawan, Imam dan Anggraini Retno Palupi. 2012. Taksonomi Bloom-Revisi Ranah Kognitif: Kerangka Landasan untuk Pembelajaran, Pengajaran, dan Penilaian. Jurnal Premiere Educandum. Vol. II No. II. Madiun: IKIP PGRI.

Hamayotsu, Kikue. 2014. Indonesia in 2014. The Year of Electing the "People's President". Journal Asian Survey. Vol. LV No. I, A Survey of Asia in 2014 (January/February 2015). University of California Press.

Hamdani dkk. 2014. Perempuan Berhati Ikhlas: Sekelumit Kisah Sudjiatmi, Ibunda Jokowi. Yogyakarta: Galang Press.

Harjali. 2011. Urgensi Pendekatan Multikultur dalam Pendidikan. Jurnal Cendekia. Vol. IX No. II. Juli-Desember 2011. Pascasarjana Universitas Negeri Malang. Hasbullah, Maisarah and Mohd Hazim Shah Abdul Murad. 2018. The Rise of Modern Science: Islam and The West. Journal Philosophy East and West. Vol. LXVIII. No. I, January 2018. University of Hawai'i Press.

Hayuningtyas, Dyah Ratri Ismi dkk. 2013. Jokowi Membangun Solo. Studi Kasus atas Gaya Kepemimpinan Wali Kota Solo dalam Proses Relokasi Pedagang Kaki Lima. Jurnal Spirits. Vol. IV No. I, November 2013.

Huntington, Samuel P. 1968. Political Order in Changing Societies. New Haven: Yale University Press.

Husaini, Adian. 2013. Filsafat Ilmu Perspektif Barat dan Islam. Yogyakarta: Gema Insani.

Ibad, Nurul. 2015. Jokowi dalam Cermin Dunia: Antara Simpati dan Sinisme. Jakarta: Penerbit Papas Sinar Sinanti.

Indriyanto, Bambang. 2014. Mengkaji Revolusi Mental dalam Konteks Pendidikan. Jurnal 
Pusat Penelitian Kebijakan, Balitbang Kemendikbud.

Instruksi Presiden Republik Indonesia Nomor 12 Tahun 2016 tentang Gerakan Nasional Revolusi Mental.

Ismail dan Wan Suhaimi. 2012. Adab dan Peradaban. Malaysia: MPH Group Printing.

Kamaruzzaman, Azmul Fahimi, et al. 2016. Al-Attas' Philosophy of History on the Arrival and Proliferation of Islam in the Malay World. International Journal of Islamic Thought. Vol. X, Dec 2016.

Kartono, Kartini dan Jenny Andari. 1989. Hygiene Mental dan Kesehatan Mental dalam Islam. Bandung: Mandar Maju.

Kementerian Koordinator Bidang Pembangunan Manusia dan Kebudayaan. 2015. Materi Sosialisasi Gerakan Nasional Revolusi Mental.

Khaldun, Abd al-Rahman Ibnu. 2005. Muqaddimah. Jilid I. Al-Dar al-Baida'.

Khan, Yahya. 2010. Pendidikan Karakter Berbasis Potensi Diri. Yogyakarta: Pelangi Publishing.

Kholiq, Abdul dkk. 1999. Pemikiran Pendidikan Islam: Kajian Tokoh Klasik dan Kontemporer. Yogyakarta: Pustaka Pelajar.

Koentjaraningrat. 2004. Kebudayaan Mentalitas dan Pembangunan. Jakarta: PT Gramedia Pustaka Utama.

Kristiawan, Muhammad. 2015. Telaah Revolusi Mental dan Pendidikan Karakter dalam Pembentukan Sumber Daya Manusia yang Pandai dan Berakhlak Mulia. Jurnal Ta'dib. Vol. XVIII No. I, Juni 2015. FKIP Universitas Muhammadiyah Sumatera Barat.

Lickona, Thomas. 1992. Educating for Character: How Our School Can Teach Respect and Responsibility. New York: Bantam Books.

Ma'arif, A. Syafi'i dkk. 1991. Pendidikan Islam Indonesia antara Cita dan Fakta. Yogyakarta: Tiara Wacana Ilmu.

Mandzur, Ibnu. 1990. Lisan Al-Arab. Beirut: Dar Shadir.
Maragustam. 2010. Mencetak Pembelajar Menjadi Insan Paripurna. Yogyakarta: Nuha Litera.

- 2015. Paradigma Revolusi Mental dalam Pembentukan Karakter Bangsa Berbasis Sinergitas Islam dan Filsafat Pendidikan. Jurnal Pendidikan Agama Islam. Vol. XI No. II. 2 Desember 2015. Yogyakarta: UIN Sunan Kalijaga.

Margana, Sri. 2014. Revolusi Mental: Konteks Historis Perubahan Mentalitas dalam Paradigma Kebudayaan. Jakarta: Pusat Penelitian dan Pengembangan Kebudayaan.

Merrill, David N. dan Bernard A. Burrola. 2015. International Education's Role in Indonesia's "Mental Revolution" A path to prosperity in the global economy?. The Indonesia Journal of Leadership, Policy, and World Affairs.

Moeleang, Lexy J. 1991. Metode Penelitian Kualitatif. Jakarta: Rosda Karya.

Mubarok, Muhammad Yakub. 2017. Problem Teologis Ideologi Komunisme. Jurnal Tsaqafah Peradaban Islam. Vol. XIII No. I, Mei 2017. Ponorogo: Unida Gontor.

Mulyasa. 2017. Revolusi Mental dalam Pendidikan. Bandung: PT. Remaja Rosdakarya.

Mursa, Muhammad Munir. 1977. Al-Tarbiyah AlIslamiyah: Ushuluha wa Tathawwuruha fi Al-Bilad Al-Arabiyah. Kairo: 'Alam Al-Kutub.

Nata, Abuddin. 2001. Pemikiran Para Tokoh Pendidikan Islam. Jakarta: PT Raja Grafindo Persada.

Notosoedirdjo, Moeljono dan Latipun. 2011. Kesehatan Mental: Konsep dan Penerapan. Malang: UMM Press.

Paharizal. 2014. Jokowi (Calon) Presiden Blusukan. Yogyakarta: Penerbit Cakrawala.

Pellokila, Jeppy. 2014. Jalan Perubahan untuk Indonesia yang Berdaulat, Mandiri, dan Berkepribadian. Jakarta.

Peraturan Menteri Koordinator Bidang Pembangunan Manusia dan Kebudayaan Republik Indonesia Nomor 3 Tahun 2017 
tentang Peta Jalan Gerakan Nasional Revolusi Mental 2017-2019.

Peraturan Menteri Koordinator Bidang Pembangunan Manusia dan Kebudayaan Republik Indonesia Nomor 4 Tahun 2017 tentang Pedoman Umum Gerakan Nasional Revolusi Mental.

Peraturan Menteri Pendidikan dan Kebudayaan Republik Indonesia Nomor 20 Tahun 2018 tentang Penguatan Pendidikan Karakter pada Satuan Pendidikan Formal. Peraturan Presiden Republik Indonesia Nomor 87 Tahun 2017 tentang Penguatan Pendidikan Karakter.

Pratiwi, Indah. 2019. Efek Program PISA terhadap Kurikulum di Indonesia. Jurnal Pendidikan dan Kebudayaan. Vol. IV No. I. Juni 2019. Jakarta: Badan Litbang Kemendikbud.

Pusat Kurikulum dan Perbukuan Badan Penelitian dan Pengembangan Kementerian Pendidikan Nasional. 2011. Panduan Pelaksanaan Pendidikan Karakter.

Pusat Pembinaan Bahasa Departemen Pendidikan dan Kebudayaan Republik Indonesia. 1994. Kamus Besar Bahasa Indonesia. Jakrta: Balai Pustaka.

Rafiek, M. 2013. Pengkajian Sastra, Kajian Praktik. Bandung: Refika Aditama.

Rahman, Amri dan Dulsukmi Kasim. 2014. Upaya Menciptakan Bangsa yang Berkarakter. Jurnal Pendidikan Karakter Berbasis Al-Qur'an. Vol. XIV No. I. Juni 2014. Al-Ulum.

Rahman, M. Zulfian dan Lena Satlita. 2016. Implementasi Program Revolusi Mental di Balai Besar POM DIY. Jurnal FIS Universitas Negeri Yogyakarta.

Rahmatiah, St.2017. Pemikiran tentang Jiwa (alNafs) dalam Filsafat Islam. Jurnal Sulesana Vol. XI No. II Tahun 2017. Makassar: Fakultas Dakwah dan Komunikasi UIN Alauddin.Saifuddin, Achmad Fedyani. 2014. Revolusi Mental: Revolusi Mental = Revolusi Pendidikan (Prosesualisme dalam Pendidikan). Jakarta: Pusat Penelitian dan Pengembangan Kebudayaan.
Saiful et al. 2018. National Movement of Mental Revolution in Developing Character Education of Indonesian Generation. Journal Advances in Social Science, Education and Humanities Research. Vol. CCLI. Annual Civic Education Conference (ACEC).

Sholekhah, Fitriatus. 2019. Pendidikan Karakter Melalui Revolusi Mental di Era Disruptif. Jurnal Program Studi PGMI. Vol. VI No. I, Maret 2019. Probolinggo: Fakultas Agama Islam Universitas Nurul Jadid.

Singarimbun, Masri dan Sofian Effendi. 1987. Metode Penelitian Survei. Jakarta: LP3ES. Siswoyo, Dwi dkk. 2008. Ilmu Pendidikan. Yogyakarta: UNY Press.

Soemardjan, Selo. 1986. Perubahan Sosial di Yogyakarta. Yogyakarta: Gadjah Mada University Press.

Subdirektorat Statistik Politik dan Keamanan. 2018. Statistik Kriminal 2018. Jakarta: Badan Pusat Statistik.

Subekti, Valina Singka. 2014. Partai Syarikat Islam Indonesia: Kontestasi Politik hingga Konflik Kekuasaan Elite. Jakarta: Pustaka Obor Indonesia.

Sugihartono dkk. 2007. Psikologi Pendidikan. Yogyakarta: UNY Press.

Sugiharto, Ugi. 1997. Ulasan Buku: Prolegomena to the Mataphysics of Islam. Jurnal Al-Hikmah. No. III. Kuala Lumpur: Forum ISTAC.

Sugiyono. 2009. Metode Penelitian Kuantitatif, Kualitatif, dan R\&D. Bandung: Penerbit Alfabeta.

Sulaiman, Fathiyah Hasan. 1964. Bahts Fi alMadzhab al-Tarbawi 'inda al-Ghazali. Mesir: Maktabah Nahdhah.

Suparno. 2017. Revolusi Mental, To Build the Character of Bureaucrats in Indonesia. International Journal of Civil Engineering and Technology (IJCIET). Vol. VIII No. VIII, August 2017. IAEME Publication.

Supelli, Karlina. 2014. Revolusi Mental: Revolusi Mental sebagai Paradigma Strategi Kebudayaan. Jakarta: Pusat Penelitian dan Pengembangan Kebudayaan. 
Supriyoko. 2014. Revolusi Mental: Pendidikan Karakter Bangsa sebagai Strategi Kebudayaan. Jakarta: Pusat Penelitian dan Pengembangan Kebudayaan.

Suryabrata, Sumadi. 2005. Metodologi Penelitian. Jakarta: Raja Grafindo Press.

Susanti, Reni dan Deswita. 2016. Revolusi Mental dalam Pandangan Akhlak. Jurnal Pendidikan Islam. Vol. I. No. I.

Syah, Ahmad. 2008. Term Tarbiyah, Ta 'lim, dan Ta'dib dalam Pendidikan Islam. Jurnal Ilmiah Keislaman Al-Fikra. Vol. VII No. I, Januari-Juli 2008. Fakultas Tarbiyah dan Ilmu Keguruan.

Syamsi, Syam Surya. 2015. Nawacita Jokowi$J K$ dalam Paradigma Pembangunan Ekonomi. Jurnal Teknologi. Vol. I No. I. September 2015. Departemen of Green Economy, Surya University.

Tafsir, Ahmad. 2005. Ilmu Pendidikan dalam Perspektif Islam. Bandung: PT Remaja Rosdakarya.

Tim Penyusun Phoenik. 2007. Kamus Besar Bahasa Indonesia. Jakarta: Pustaka Phoenik.

Undang-Undang Nomor 20 Tahun 2003 tentang Sistem Pendidikan Nasional.

United Nations Development Programme. 2014. Human Develompment Index (HDI).

Warburton, Eve. 2018. A New Developmentalism in Indonesia. Journal of Southeast Economies. Vol. XXXV No. III, Special Issue: The Indonesian Economy in Transition: Policy Challenges in the Jokowi Era and Beyond (Part II) (December 2018). Yusof Ishak Institute.
Weber, Max. 2002. Sosiologi Agama. Terj. Muhammad Yamin. Yogyakarta: Penerbit Ircisod.

- 2006. Sosiologi. From Max Weber: Essays in Sociology. Terj. Noorkholis. Yogyakarta: Pustaka Pelajar.

Widjiastuti, Agustin. 2016. The Form of Youth Manners through Mental Revolution: Case Study in Indonesia. Journal of Law, Policy and Globalization. Vol. XLVI.

Widigdo, Mohammad Syifa Amin. 2004. Pergulatan Politik dalam Pemilu 2004: Kaum Muda dan Pemilu 2004. Jakarta: PT Raja Grafindo Persada.

- Tanpa tahun. Reorientasi Pemikiran Pendidikan dalam Islam (Beyond Ideology). Jurnal Cendekia.

Widodo, Jokowi. 2014. Revolusi Mental. Harian Kompas 10 Mei 2014.

Williams, Michael C. 2003. Arit dan Bulan Sabit: Pemberontakan Komunis 1926 di Banten. Terj. Chandra Utama. Yogyakarta: PT Syarikat.

Wiyono, B.B. 2007. Metodologi Penelitian Pendekatan Kuantitatif, Kualitatif, dan Action Research. Malang: UN Malang.

Yuda, Hanta dan Tim. 2014. Jejak Para Pemimpin. Jakarta: PT Gramedia Pustaka Utama.

Yuwono, Ismantoro Dwi. 2014. Janji-janji Jokowi-JK: (Jika) Rakyat Tidak Sejahtera, Turunkan Saja Mereka!. Yogyakarta: Media Pressindo.

Zeid, Mestika. 2000. Metode Penelitian untuk Skripsi dan Tesis Bisnis. Jakarta: Raja Grafindo Persada. 